\title{
Characterizing Volcanic Ash Elements from the 2015 Eruptions of Bromo and Raung Volcanoes, Indonesia
}

\author{
Arinto Y.P. Wardoyo ${ }^{1 *}$, Johan A.E. Noor ${ }^{1}$, Gereon Elbers ${ }^{2}$, \\ Sandra Schmitz ${ }^{2}$, Sascha T. Flaig ${ }^{2}$, Arif Budianto ${ }^{1}$ \\ ${ }^{1}$ Laboratory of Air Quality and Astro Imaging, Department of Physics, University of Brawijaya, \\ Malang, East Java, Indonesia \\ ${ }^{2} \mathrm{FH}$ Aachen University of Applied Sciences, Juelich, Germany
}

Received: 12 August 2018

Accepted: 21 October 2018

\begin{abstract}
The volcanic eruptions of Mt. Bromo and Mt. Raung in East Java, Indonesia, in 2015 perturbed volcanic materials and affected surface-layer air quality at surrounding locations. During the episodes, the volcanic ash from the eruptions influenced visibility, traffic accidents, flight schedules, and human health. In this research, the volcanic ash particles were collected and characterized by relying on the detail of physical observation. We performed an assessment of the volcanic ash elements to characterize the volcanic ash using two different methods which are aqua regia extracts followed by MP-AES and XRF laboratory test of bulk samples. The analysis results showed that the volcanic ash was mixed of many materials, such as $\mathrm{Al}, \mathrm{Si}, \mathrm{P}, \mathrm{K}, \mathrm{Ca}, \mathrm{Ti}, \mathrm{V}, \mathrm{Cr}, \mathrm{Mn}, \mathrm{Fe}, \mathrm{Ni}$, and others. Fe, $\mathrm{Si}, \mathrm{Ca}$, and $\mathrm{Al}$ were found as the major elements, while the others were the trace elements $\mathrm{Ba}, \mathrm{Cr}, \mathrm{Cu}, \mathrm{Mn}, \mathrm{P}, \mathrm{Mn}, \mathrm{Ni}, \mathrm{Zn}, \mathrm{Sb}$, $\mathrm{Sr}$, and $\mathrm{V}$ with the minor concentrations. XRF analyses showed that Fe dominated the elements of the volcanic ash. The XRF analysis showed that Fe was at 35.40\% in Bromo and $43.00 \%$ in Raung of the detected elements in bulk material. The results of aqua regia extracts analyzed by MP-AES were $1.80 \%$ and $1.70 \%$ of Fe element for Bromo and Raung volcanoes, respectively.
\end{abstract}

Keywords: characterization, volcanic ash, Bromo Mountain, Raung Mountain

\section{Introduction}

Natural disasters such as volcanic eruptions become significant natural processes that emit volcanic materials such as gaseous species or aerosol particles

*e-mail: a.wardoyo@ub.ac.id

into the atmosphere. The implication of the eruption of a volcano was generated from heavy volcanic ash [1]. As an example, the eruption of Mt. Kelud (East Java, Indonesia) in 2014 generated volcanic ash without any warning. The volcanic ash even was carried as far as approximately $350 \mathrm{~km}$ to the west side [2]. A similar disaster occurred in Iceland in May 2011, when the Grimsvötn eruption affected the surface-layer air quality of the surrounding area [3]. The recent examples 
of disastrous volcanic eruptions in terms of large amounts of volcanic ash emissions were the 2016 Bromo (stratovolcano, $2.329 \mathrm{~m}$ a.s.1.) and Raung (stratovolcano, $3.332 \mathrm{~m}$ a.s.1,) eruptions in East Java, Indonesia. These eruptions emitted volcanic ash particles that were transported toward several locations' airspaces, such as Malang, Blitar, Jember, Probolinggo, Bondowoso, and Kediri.

Especially for volcanic ash, this volcanic material generally was described as the fragmented material generated from the volcanic eruption and always mixed with other pollutants [3]. It has a geochemical composition and mineralogy characteristic and consists of fragments of minerals and volcanic glass. It can also be classified into particulate matter (PM) with different diameters and chemical compounds [4]. This volcanic ash can be found in the form of aerosol, $\mathrm{PM}_{0.5}, \mathrm{PM}_{2.5}$, and $\mathrm{PM}_{10}$ [5-7].

Volcanic ash has a potential to cause serious disturbances in the infrastructure and human health [8]. The deposited airborne volcanic ash in the pulmonary system can be detected in the alveolar and tracheobronchial regions of the lung [9]. Furthermore, these negative impacts still depended on many parameters, such as ash fall thickness, the duration and level of the ash fall, the grain size and chemical compounds, surface chemistry, and moisture content [6]. For these reasons, the deep observations and investigations are very important for managing the impacts of volcanic ash. Numerous studies have been conducted to investigate the adverse effects of volcanic ash.
The investigation can be linked to a characterization of volcanic ash. The characterization can be done in simple or complex mitigations. However, there is still limited research about the volcanic ash characterization in Indonesia, such as from Bromo and Raung volcanoes. Therefore, the intention of this study was to characterize the volcanic ash of Bromo and Raung from the eruptions in 2015. The aim of this study was to analyze the volcanic ash elements that might have an impact on the surrounding environment. In this study, we present the element characterization using MP-AES for an extractable fraction and XRF analyses for bulk samples. The proximal ash fall samples collected close to Bromo and Raung volcanoes were used as the reference material. By understanding the character of the volcanic ash, it will make it simple to generate other ongoing products and studies.

\section{Materials and Methods}

\section{Sample Collection}

Ash from two eruptions (Bromo and Raung in 2015) was sampled in different sites of the affected zone of Java Island, Indonesia: Malang Regency $\left(7.9797^{\circ} \mathrm{S}\right.$ $\left.112.6304^{\circ} \mathrm{E}\right)$ and Bondowoso Regency (7.9404 ${ }^{\circ} \mathrm{S}$ $113.9834^{\circ} \mathrm{E}$ ) (Fig. 1). These samples were collected on plastic surfaces placed around the eruption areas. There were 8.41 grams (Bromo) and 32.73 grams (Raung) of ground-deposited volcanic ash from July 2015. These samples were transported to the laboratory

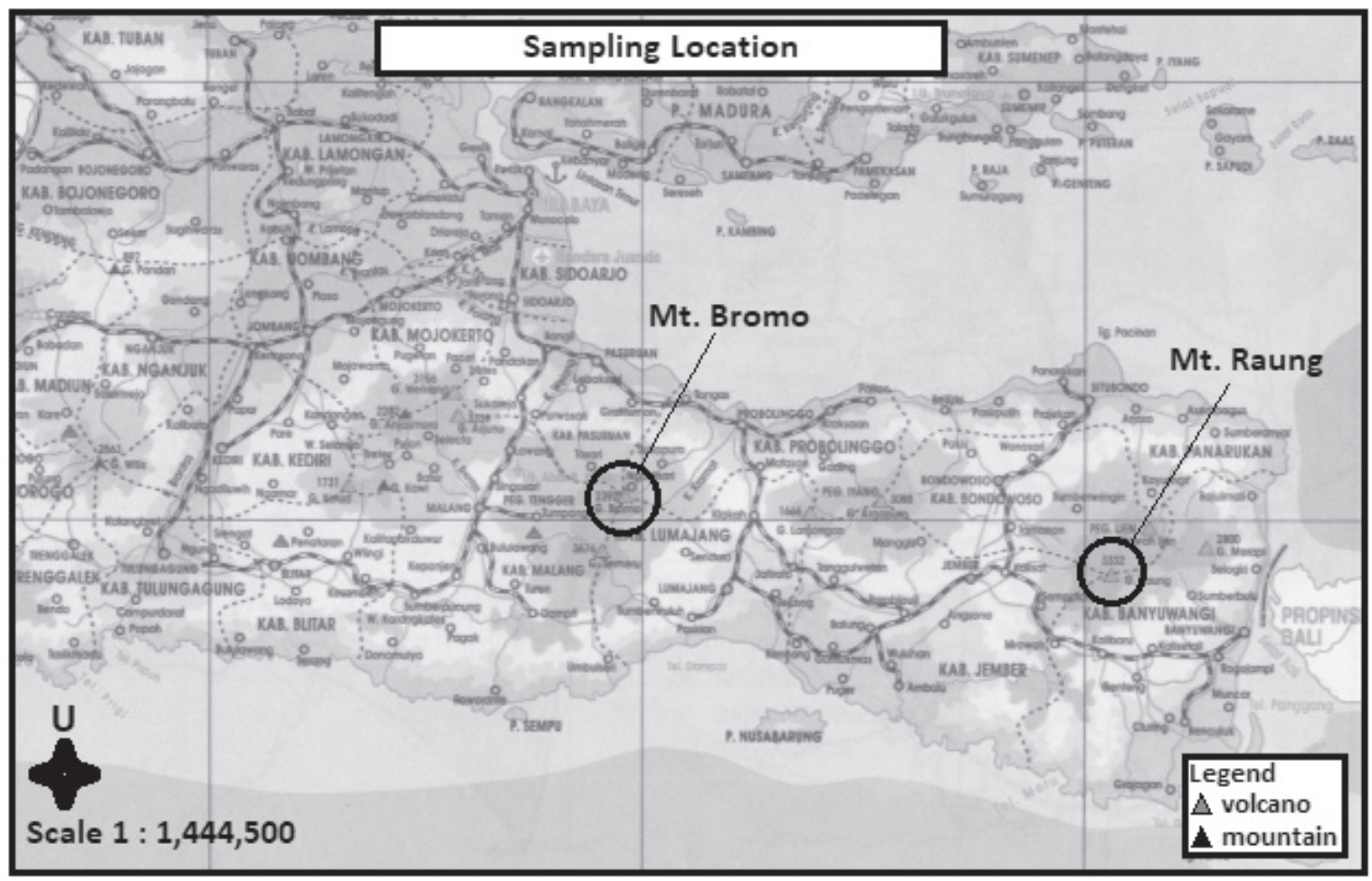

Fig. 1. Geology of the Bromo and Raung volcanoes. 
in polyethylene bags and stored in polyethylene tubes. Due to the high relative humidity, all samples were collected from single ashfall events as clean as possible. Samples collected from accumulation events will have high potency to be exposed by moisture that can influence their physical profiling. They were collected in succession at the same location for more than one eruption phase.

\section{Microwave Plasma Atomic Emission Spectrometry (MP-AES)}

The sample preparation was carried out by aqua regia extraction under high pressure according to the reference method described in (Norm DIN EN ISO 16174, 2012). About $1 \mathrm{~g}$ of the volcanic ash was weighed and transferred to the digestion vessel. Two drops of distilled water, $2 \mathrm{ml}$ concentrated $(65 \%)$ nitric acid and $6 \mathrm{ml}$ concentrated $(37 \%)$ hydrochloric acid were added to the volcanic ash. The closed digestion vessels were placed in the microwave digestion system, heated at a rate of $10^{\circ} \mathrm{C} / \mathrm{min}$ to a temperature of $180^{\circ} \mathrm{C}$ and remained there for $10 \mathrm{~min}$. After cooling down to room temperature the sample was filtered into a $50 \mathrm{ml}$ volumetric flask. The solid remaining in the digestion vessel was transferred into the funnel using distilled water and washed with $5 \mathrm{ml}$ diluted (about $2.3 \%$ ) nitric acid, and the volumetric flask was filled with distilled water. Parallel to the digestion, a reagent blank test digestion was carried out. The sample solutions were stored in a refrigerator. Microwave Plasma Atomic Emission Spectrometry (Agilent Technologies, 4200 MP-AES) was used to analyze the volcanic ash sample extracts quantitatively. Each sample solution was filtered using a syringe filter $(0.45 \mu \mathrm{m})$. The analysis used calibration solutions (Calibration mix 2 (Part. No. 6610030600) and
Calibration mix majors (Part. No. 6610030700), Agilent Technologies), "Matrix" solution (20 ml $\mathrm{HNO}_{3}$ (65\%, suprapur MERCK) and $60 \mathrm{ml} \mathrm{HCl} \mathrm{(37 \% )} \mathrm{in} 500 \mathrm{ml}$, filled up with distilled water), and stock solution. This method measured the elements of $\mathrm{Ag}, \mathrm{Al}, \mathrm{As}, \mathrm{Ba}, \mathrm{Be}$, $\mathrm{Cd}, \mathrm{Co}, \mathrm{Cr}, \mathrm{Cu}, \mathrm{Mn}, \mathrm{Ni}, \mathrm{Pb}, \mathrm{Se}, \mathrm{Th}, \mathrm{Tl}, \mathrm{U}, \mathrm{V}$, and $\mathrm{Zn}$ for the Calibration mix 2 and $\mathrm{Ca}, \mathrm{Fe}, \mathrm{K}, \mathrm{Mg}$, and $\mathrm{Na}$ for the Calibration mix majors. The speed of the pump was $15 \mathrm{r} / \mathrm{min}$, with the stabilization time of $15 \mathrm{~s}$ (sample uptake time $15 \mathrm{~s}$ ). The concentration of the analyzed element was calculated by:

$$
\text { Concentration }=\frac{\bar{x}_{a w} \cdot d \cdot V_{\text {solution }}}{m_{\text {ash }}}
$$

The mass of ash sample is shown by $m_{a s h}$. $d$ is the dilution factor (see Table 1). $V_{\text {solution }}$ was $50 \mathrm{ml}$. Calibration function was calculated by:

$$
w_{i}=\frac{s_{i}^{-2}}{\sum s_{i}^{-2} / m}
$$

Weighted calibration is referred to $w_{i}$ (weighting factor), while $s_{i}$ and $m$ represent the standard deviation of $i$ (calibration solution) and the number of calibration solutions including blank, respectively. To calculate the statistical parameters for each solution (calibration and digested sample), we measured them three times. The complete analysis procedure sample preparation, calibration and MP-AES measurement were carried out two times for both Bromo and Raung ash samples on different days in order to check the reproducibility. Not all the elements present in the calibration solutions could be determined quantitatively in the volcano ash samples because of spectral interference caused by major elements.

\begin{tabular}{|c|c|c|c|c|}
\hline No. & Elements & $\begin{array}{l}\text { Dilution of the Sample Solu- } \\
\text { tion }\end{array}$ & $\begin{array}{c}\text { Calibration Solutions } \\
(\mathrm{mg} / \mathrm{L})\end{array}$ & Calibration Function Concentration $(\mathrm{mg} / \mathrm{L})$ \\
\hline 1 & $\mathrm{Ba}$ & - & $0.4 ; 0.6 ; 1 ; 2 ; 3$ & Intensity $=503 \cdot 10^{3 *}$ Concentration +0.081 \\
\hline 2 & $\mathrm{Cr}$ & - & $0.4 ; 0.6 ; 1 ; 2 ; 3$ & Intensity $=35,6 \cdot 10^{3 *}$ Concentration- 0.12 \\
\hline 3 & $\mathrm{Cu}$ & - & $0.4 ; 0.6 ; 1 ; 2 ; 3$ & Intensity $=110 \cdot 10^{3 *}$ Concentration -0.367 \\
\hline 4 & V & - & $3 ; 5 ; 8 ; 12 ; 16$ & Intensity $=8.86 \cdot 10^{3 *}$ Concentration- 0.15 \\
\hline 5 & $\mathrm{Mn}$ & - & $3 ; 5 ; 8 ; 12 ; 16$ & Intensity $=42.2 \cdot 10^{3 *}$ Concentration -0.018 \\
\hline 6 & $\mathrm{Al}$ & $1: 200$ & $3 ; 5 ; 8 ; 12 ; 16$ & Intensity $=31.5 \cdot 10^{3 *}$ Concentration- 16.3 \\
\hline 7 & $\mathrm{Fe}$ & $1: 200$ & $1 ; 4 ; 8 ; 12 ; 16$ & Intensity $=8.12 \cdot 10^{3 *}$ Concentration- 2.29 \\
\hline 8 & $\mathrm{Mg}$ & $1: 200$ & $0.1 ; 0.2 ; 0.5 ; 1 ; 2$ & Intensity $=204 \cdot 10^{3 *}$ Concentration +9.11 \\
\hline 9 & $\mathrm{Ca}$ & $1: 2000$ & $0.5 ; 1 ; 1.5 ; 2 ; 3$ & Intensity $=892 \cdot 10^{3 *}$ Concentration -341 \\
\hline 10 & K & $1: 20$ & $0.5 ; 1 ; 1.5 ; 2 ; 3$ & Intensity $=44.9 \cdot 10^{3 *}$ Concentration +20.6 \\
\hline 11 & $\mathrm{Na}$ & $1: 200$ & $0.5 ; 1 ; 2 ; 3 ; 4$ & Intensity $=325 \cdot 10^{3 *}$ Concentration +615 \\
\hline
\end{tabular}

Table 1. Groups of the different elements for the measurement by MP-AES and calibration. 


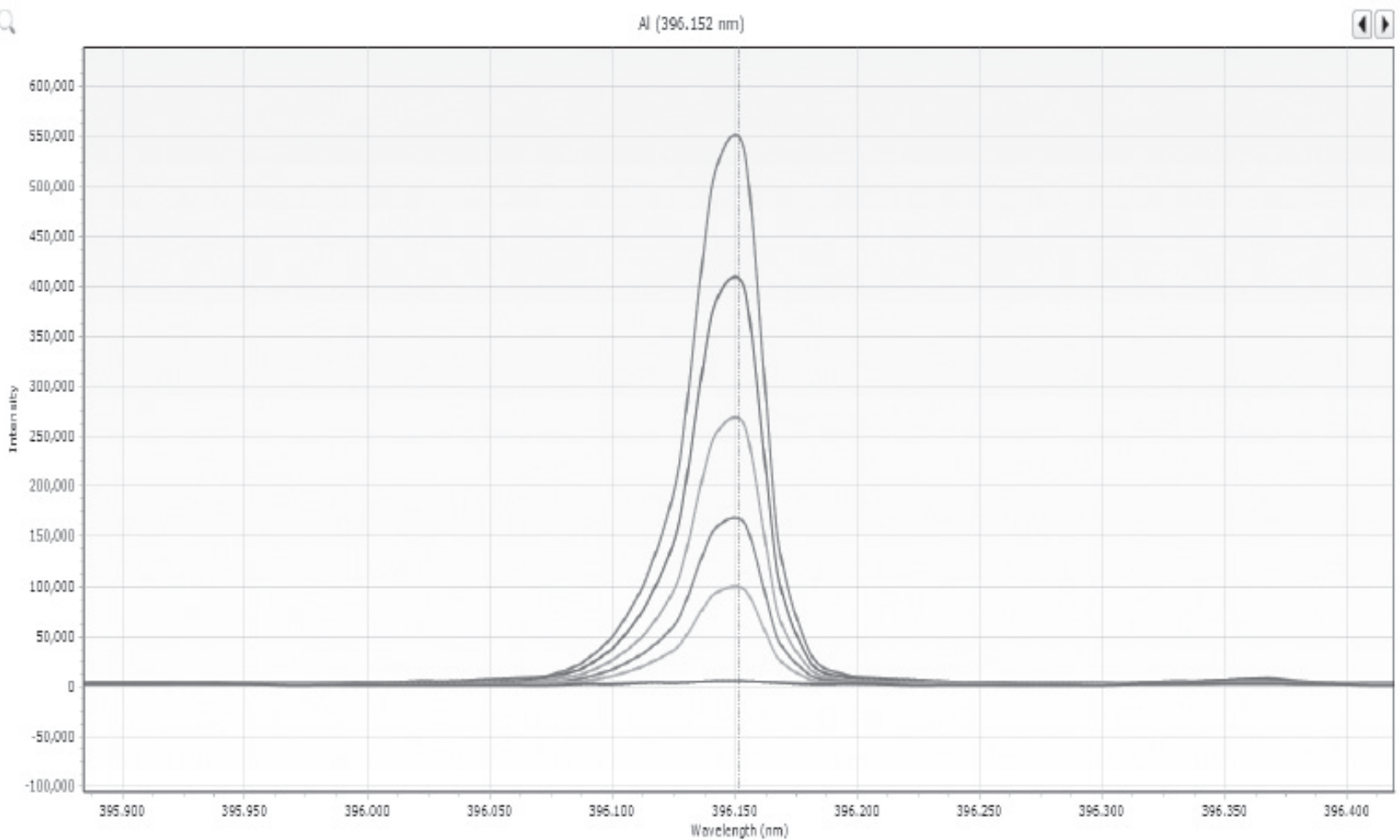

Fig. 2. Spectra of $\mathrm{Al}$ in different concentrations used for calibration.

\section{XRF Spectroscopy}

An XRF (x-ray fluorescence spectroscopy, PANalytical, Model MiniPal 4) test was used to determine the elemental composition of the volcanic ash qualitatively. The information of the components was interpreted as a spectrum graph. The results were expressed as the element concentration in weight percentage $(w t \%)$ by the reference $100 \%$ representing the sum of the detected elements.

\section{Results and Discussion}

Microwave Plasma Atomic Emission Spectrometry (MP-AES)

In order to measure the different elements in the sample solutions, it was necessary to group up the elements. The dilution of the sample solution and the calibration solution used are interpreted in Table 1 and Fig. 2 (the representative spectra of $\mathrm{Al}$ in different concentrations of the calibration solutions). Results

Table 2. Mass-Concentrations of the elements in aqua regia extracts $(p=0.95)$.

\begin{tabular}{|c|c|c|c|c|}
\hline No. & Elements & Bromo & Raung & State \\
\hline 1 & $\mathrm{Ba}$ & $49.9( \pm 1) \mathrm{ppm}$ & $29.0( \pm 0.7) \mathrm{ppm}$ & \multirow{5}{*}{ Traces element } \\
\hline 2 & $\mathrm{Cr}$ & $11.0( \pm 1) \mathrm{ppm}$ & $5.9( \pm 0.6) \mathrm{ppm}$ & \\
\hline 3 & $\mathrm{Cu}$ & $64.5( \pm 5) \mathrm{ppm}$ & $40.3( \pm 3) \mathrm{ppm}$ & \\
\hline 4 & $\mathrm{Mn}$ & $275.0( \pm 19) \mathrm{ppm}$ & $351( \pm 49) \mathrm{ppm}$ & \\
\hline 5 & V & $66.7( \pm 7) \mathrm{ppm}$ & $46.5( \pm 8) \mathrm{ppm}$ & \\
\hline 6 & $\mathrm{Al}$ & $1.5( \pm 0.24) \%$ & $2.9( \pm 1) \%$ & \multirow{6}{*}{ Major elements } \\
\hline 7 & $\mathrm{Ca}$ & $1.2( \pm 0.3) \%$ & $2.5( \pm 0.2) \%$ & \\
\hline 8 & $\mathrm{Fe}$ & $1.8( \pm 0.1) \%$ & $1.7( \pm 0.1) \%$ & \\
\hline 9 & $\mathrm{~K}$ & $1.5( \pm 0.2) \%$ & $0.95( \pm 0.2) \%$ & \\
\hline 10 & $\mathrm{Mg}$ & $3.6( \pm 0.5) \%$ & $8.2( \pm 1.4) \%$ & \\
\hline 11 & $\mathrm{Na}$ & $4.2( \pm 0.5) \%$ & $6.0( \pm 1.4) \%$ & \\
\hline
\end{tabular}


from the analysis of MP-AES in the volcanic ash samples of the volcanoes Bromo and Raung are of a similar magnitude with a little difference. Table 2 below interprets the analysis results of the aqua regia extractable fraction from Bromo and Raung ash.

Eleven elements were quantified in both Bromo and Raung ash samples. The concentrations are given in Table 2, and Fig. 3(a-b) are the mean values of two complete analyses of each sample. They differed by less than $10 \%$ only in the case of $\mathrm{Cr} 20 \%$. This indicates a good reproducibility of the analysis for all elements and a high homogeneity of the ash samples. In parentheses we give the confidence interval, which refers to the calibration function and the standard deviation of the sample measurement. In Fig. 3(a-b) the dominant of the detected elements are $\mathrm{Fe}, \mathrm{Al}$, and $\mathrm{Ca}$. Interpreting the data in Table 3 it must be considered that the elements $\mathrm{Si}$ and $\mathrm{O}$ are not determined here, but it is well known

a)
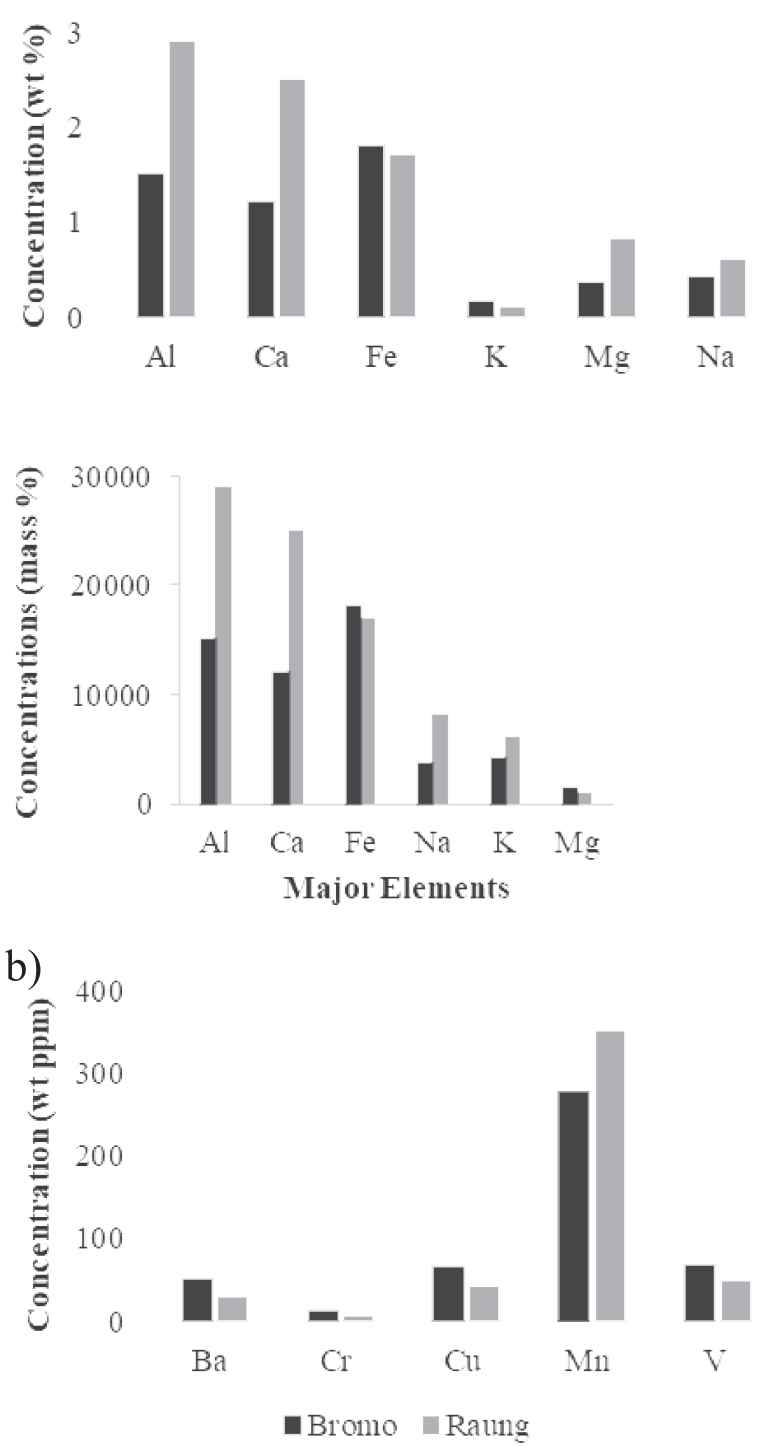

Fig. 3. The average concentration of elements measured in the aqua regia extracts of volcanic ash of Bromo and Raung volcanoes by MP-AES analysis: a) major and b) trace. that they contribute to volcanic ash in a high amount. Mass concentration of more than $60 \% \mathrm{SiO}_{2}[10]$ and up to $70 \%$ were measured (Wahyuni, 2016) for Merapi. Even $77 \% \mathrm{SiO}_{2}$ have been found in the volcanic glass of Tyatya Volcano [11].

As mentioned in the methodology section, a solid residue after aqua regia extraction remained. The masses of unsoluble dried residue after aqua regia extraction of Raung sample was $58 \%$, and in the case of Bromo even $82 \%$. This is not surprising because in volcanic ash a high amount of $\mathrm{SiO}_{2}$ and in aqua regia unsoluble silicates or oxides are expected. The higher amount of $\mathrm{SiO}_{2}$ in Bromo sample could explain the lower concentration of major elements $\mathrm{Al}$ and $\mathrm{Ca}$ because we calculated the concentrations in relation to the complete sample mass. The color of both samples is dark grey, the Bromo sample is a little lighter, which supports the interpretation of a higher amount of $\mathrm{SiO}_{2}$ and/or colorless silicates and oxides. In literature, often the exact acid digestion parameters for volcanic ash analysis are not given (e.g., [10, 12], and in some cases they are similar to ours [13]. Thus we conclude that the concentrations reported do not include the insoluble fraction, or it is calculated as different $\mathrm{SiO}_{2}$ up to $100 \%$ (Wahyuni, 2016). Lumpp et al. [14] compared different digestion techniques for element analysis of silicates containing airborne dust and dust deposition. They report that only with digestion by acid mixtures containing HF can complete decomposition be achieved, but also for the most metals using aqua regia very high recoveries were observed, with the exception of $\mathrm{Cr}(62 \%), \mathrm{Al}$, and $\mathrm{Na}$ (50-80\%). Thus we conclude that in the residue of the aqua regia extracts of Bromo and Raung samples, major elements like $\mathrm{Al}$ and $\mathrm{Na}$ are partially present in poorly soluble silicates or oxides. It should be mentioned that we found in both samples a very high amount of black magnetic particles, which indicates a high concentration of $\mathrm{Fe}_{3} \mathrm{O}_{4}$. This fact agrees well with the very dark color of the complete samples. The low concentrations of Fe in the aqua regia extracts correspond to the poor acid solubility of $\mathrm{Fe}_{3} \mathrm{O}_{4}$.

\section{XRF Spectroscopy}

An XRF (x-ray fluorescence spectroscopy, PANalytical, Model MiniPal 4) test was used to determine the elemental composition of the volcanic ash qualitatively. The information of the components was interpreted as a spectrum graph (Fig. 4). Ash characterization based on the XRF analyses showed that $\mathrm{Fe}, \mathrm{Si}, \mathrm{Ca}$, and $\mathrm{Al}$ are the major constituents of both Bromo and Raung ash. These elements became the highest concentrations of the main elements. Significant differences of $\mathrm{Cr}, \mathrm{Yb}$, and $\mathrm{Zn}$ were found as the trace elements. The concentrations of $\mathrm{Cr}, \mathrm{Yb}$, and $\mathrm{Zn}$ were lower. The trend of Bromo ash is quite similar to Raung ash. A little difference is found in the ash elements of Mt. Raung. We did not find the elements $\mathrm{P}, \mathrm{Rb}$, and $\mathrm{Ba}$ in the volcanic ash of Raung. 

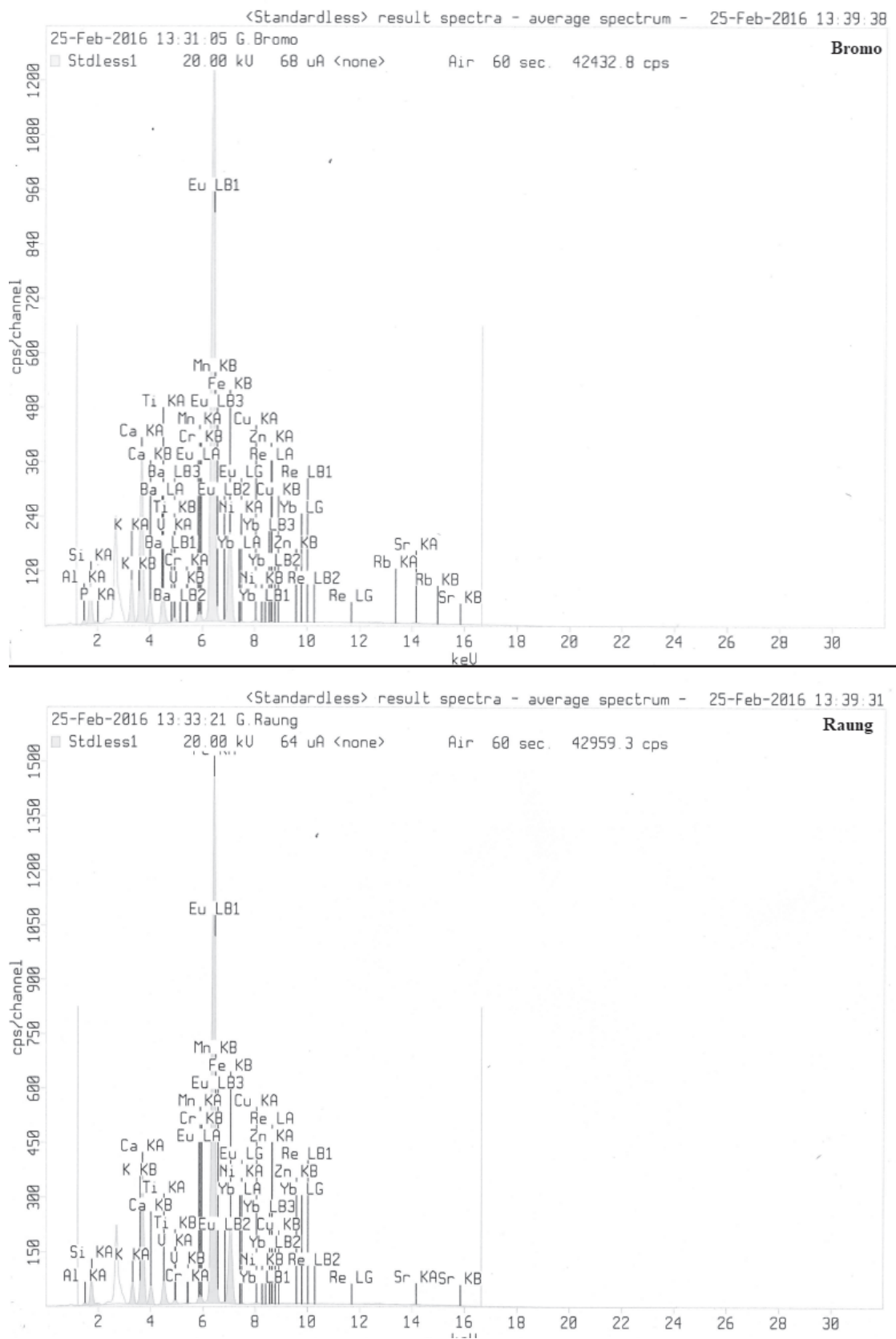

Fig. 4. Volcanic ash characteristics resulted by the XRF analyses.

The results of volcanic ash characterization and their chemical compounds derived by XRF are shown in Table 3. They are shown qualitatively and expressed as the concentration (percentage) calculated up to $100 \%$, referring to the sum of the detected elements. Based on Table 3, the comparison of 16 elements detected in the volcanic ash of Bromo reveals that the element of $\mathrm{Fe}(35.4 \%)$ is much higher compared to other elements. The concentration of $\mathrm{Si}$ is $9.1 \%$ lower than Fe. An identical result can be seen in Raung, which has similar volcanic ash elements, where Fe dominates the element concentration $(43.0 \%)$. The element of $\mathrm{Si}$ only is $22.1 \%$, in which this concentration is $20.9 \%$ lower than Fe. It is remarkable that the concentrations of $\mathrm{Fe}$ and $\mathrm{Ca}$ are significantly higher compared to other volcanic ash reported in the literature $[12,15,16]$. The high amount of $\mathrm{Fe}$ agrees very well with the magnetic property and the dark color of the ash samples, which indicate $\mathrm{Fe}_{3} \mathrm{O}_{4}$ as a dominant compound. According to all results above, both Bromo and Raung have similar ash characteristics. Because XRF is not able to detect elements with an atomic number lower than 9 (fluorine), the oxygen concentration is not included in Table 3. In order to estimate the influence of oxygen present in the ash on the mass concentration of the elements in relation to the mass of the complete sample, we calculated the amount of oxygen by the assumption that the major elements are bound as oxides. In that case, the concentrations listed in Table 3 must be multiplied by the factor 0.61 (Bromo) or 0.62 (Raung). 
Table 3. Concentration (wt \%) of the elements in the volcanic ash from XRF analysis.

\begin{tabular}{|c|c|c|c|c|}
\hline No. & Elements & Bromo & Elements & Raung \\
\hline 1 & $\mathrm{Al}$ & 8.50 & $\mathrm{Al}$ & 7.50 \\
\hline 2 & $\mathrm{Si}$ & 26.30 & $\mathrm{Si}$ & 22.10 \\
\hline 3 & $\mathrm{P}$ & 0.54 & $\mathrm{~K}$ & 3.59 \\
\hline 4 & $\mathrm{~K}$ & 5.51 & $\mathrm{Ca}$ & 18.20 \\
\hline 5 & $\mathrm{Ca}$ & 18.10 & $\mathrm{Ti}$ & 2.47 \\
\hline 6 & $\mathrm{Ti}$ & 2.41 & $\mathrm{~V}$ & 0.16 \\
\hline 7 & $\mathrm{~V}$ & 0.10 & $\mathrm{Cr}$ & 0.08 \\
\hline 8 & $\mathrm{Cr}$ & 0.07 & $\mathrm{Mn}$ & 0.69 \\
\hline 9 & $\mathrm{Mn}$ & 0.59 & $\mathrm{Fe}$ & 43.00 \\
\hline 10 & $\mathrm{Fe}$ & 35.40 & $\mathrm{Ni}$ & 0.16 \\
\hline 11 & $\mathrm{Ni}$ & 0.16 & $\mathrm{Cu}$ & 0.25 \\
\hline 12 & $\mathrm{Cu}$ & 0.23 & $\mathrm{Zn}$ & 0.02 \\
\hline 13 & $\mathrm{Zn}$ & 0.03 & $\mathrm{Sr}$ & 1.00 \\
\hline 14 & $\mathrm{Rb}$ & 0.32 & $\mathrm{Eu}$ & 0.40 \\
\hline 15 & $\mathrm{Sr}$ & 0.86 & $\mathrm{Yb}$ & 0.00 \\
\hline 16 & $\mathrm{Eu}$ & 0.40 & & \\
\hline 17 & $\mathrm{Yb}$ & 0.01 & & \\
\hline & & & & \\
\hline
\end{tabular}

Data of Bromo and Raung are rare in the literature. The measured concentrations of $\mathrm{Fe}$ and $\mathrm{Al}$ are in the same magnitude but lower than that found in the ash of Merapi as measured by thermal and epithermal neutron activation analysis: $\mathrm{Fe} 5 \%$, Al 13\%, Ca not detected [16]. The concentration of $\mathrm{K}(1.7 \%)$ is about 10 times higher as in Bromo and Mn (1\%) is about 3-4 times higher. Element concentrations in Merapi volcanic ash have been determined also using AAS and ICP-OES (Wahyuni 2016). These data are comparable to our results, since the analysis methods are similar. Wahyuni
(2016) was found at different locations on Merapi Mountain: Al 8-10\%, Ca 2-6\%, Fe 5-6\%, K 1.7-1.9\%, $\mathrm{Mg} 1.7 \%$, Mn $0.17 \%$, and $\mathrm{Na} 2.7 \%$. These concentrations are in plausible agreement with ours concerning the fact that we compared different volcanoes of Java, which may contain different amounts of $\mathrm{SiO}_{2}$ and other constituents. Kusmartini et al. [12,15] analyzed volcanic ash of Mt. Sinabung and compared the elemental concentrations with volcanoes of other regions. They found $11.8 \mathrm{ppm} \mathrm{Cr}$ for Mt. Sinabung, which is in excellent agreement with our results for Bromo (Table 2). In volcanic ash from the South Andes, $\mathrm{Cu}$ concentrations between $8.45 \mathrm{ppm}$ and $108.7 \mathrm{ppm}$ were measured, which again is very similar to the data we found for Bromo and Raung [15]. The concentrations of the other trace elements in Table 3 also are in good agreement with data from the ash of other volcanoes $[12,15]$.

Volcanic ash particles indeed consisted of the main components $\mathrm{Fe}, \mathrm{Si}, \mathrm{Al}, \mathrm{O}, \mathrm{Na}$, and other chemical compounds in varying concentrations [17, 18]. These results were similar to the composition of Icelandic volcanic ash as reported in the literature [19] with Fe, $\mathrm{Si}, \mathrm{Ca}$, and $\mathrm{Al}$ as the parts of the major elements and $\mathrm{Ti}$, $\mathrm{Mn}$, and $\mathrm{P}$ as the trace elements. Differences between the two different volcanic ashes for this eruption were not mainly manifest in the ash componentry. These results showed slightly different leaching characteristics. The main difference can be seen in the existence of $\mathrm{Fe}, \mathrm{Si}, \mathrm{Ca}$, and $\mathrm{Al}$ in the XRF results (as the main elements) and only $\mathrm{Fe}, \mathrm{Ca}$, and $\mathrm{Al}$ in aqua regia extracts measured by MP-AES (as the main elements) (Fig. 5). In another side, the concentrations of $\mathrm{Fe}, \mathrm{Ca}$, and Al have mostly been found. This likely indicates greater contents of these three elements as the main ash componentry of Bromo and Raung. Moreover, remobilization of the ash deposits by the wind after an eruption can disturb and influence the data [8]. This re-mobilization, as expected, can influence the results of the XRF and MP-AES profiling. The concentration of the detected elements also depends on the distance of

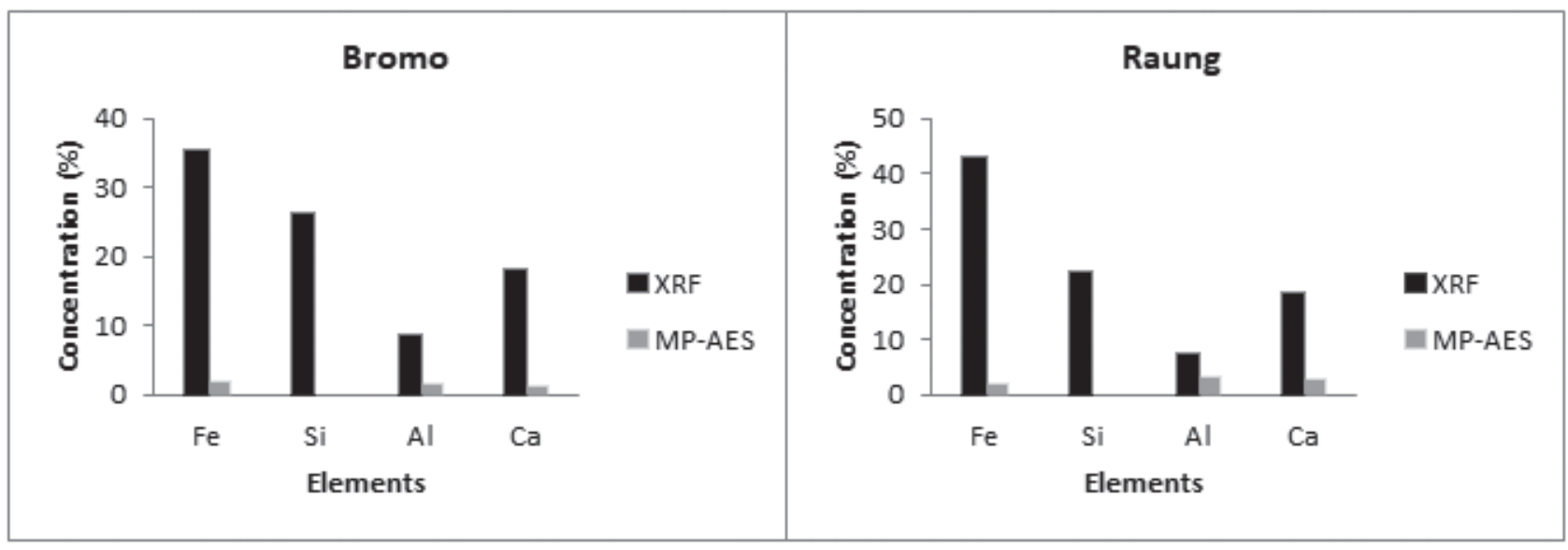

Fig. 5. The results of XRF and MP-AES (aqua regia extracts) analysis (major elements). 
the vent area and the sampling area. These differences can influence the ash accumulation rate due to the different ash deposition abilities and the size of the major and trace elements of the volcanic ash $[13,20]$.

\section{Conclusions}

The presence of the major and trace elements in the volcanic ash of Bromo and Raung volcanoes (eruptions: July 2015) has been analyzed in this study. Very similar element concentrations were found in Bromo and Raung samples. Remarkable high concentrations of $\mathrm{Fe}$ and $\mathrm{Ca}$ have been measured compared to other volcanic ash described in the literature. The dominating element is $\mathrm{Fe}$ bound in magnetite $\mathrm{Fe}_{3} \mathrm{O}_{4}$. The concentrations of trace elements in the volcanic ash soluble in aqua regia agree well with those reported for other volcanoes.

\section{Acknowledgements}

This work was supported by Brawijaya University through the Improving Research Quality Project for World-Class Universities. All authors are grateful to Brawijaya University Malang Indonesia and FH Aachen University of Applied Sciences in Juelich, Germany for providing funding and collaboration.

\section{Conflict of Interest}

The authors declare no conflict of interest.

\section{References}

1. BANI P., BOUDON G., BALCONE-BOISSARD H., DELMELLE P., QUINIOU T., LEFÈVRE J., GARAEBITI E., HIROSHI S., LARDY M. The 2009-2010 eruption of Gaua volcano (Vanuatu archipelago): Eruptive dynamics and unsuspected strong halogens source. Journal of Volcanology and Geothermal Research, 322, 63, 2016.

2. THIRUCHELVAM C. Chemistry and Biotechnology Characterisation of volcanic ash from Kelud eruption of $13^{\text {th }}$ February 2014 by different analytical methods. Thesis, Aachen University of Applied Sciences Jülich Campus Department: Germany, 2016.

3. KERMINEN V.M., NIEMI J.V., TIMONEN H., AURELA M., FREY A., CARBONE S., SAARIKOSKI S., TEINILÄ K., HAKKARAINEN J., TAMMINEN J., VIRA J., PRANK M., SOFIEV M., HILLAMO R. Characterization of a volcanic ash episode in southern Finland caused by the Grimsvötn eruption in Iceland in May 2011. Atmospheric Chemistry and Physics, 11, 12227, 2011.

4. TEPE N., BAU M. Importance of nanoparticles and colloids from volcanic ash for riverine transport of trace elements to the ocean: Evidence from glacial-fed rivers after the 2010 eruption of Eyjafjallajökull Volcano, Iceland. Science of The Total Environment, 488-489, 243, 2014.
5. CAHILL C.F., RINKLEFF P.G., DEHN J., WEBLEY P.W., CAHILL T.A., BARNES D.E. Aerosol measurements from a recent Alaskan volcanic eruption: Implications for volcanic ash transport predictions. Journal of Volcanology and Geothermal Research, 198, 76, 2010.

6. JONES T., BÉRUBÉ K. The bioreactivity of the sub-10 $\mu \mathrm{m}$ component of volcanic ash: Soufrière Hills volcano, Montserrat. Journal of Hazardous Materials, 194,128, 2011.

7. WEBER K., ELIASSON J., VOGEL A., FISCHER C., POHL T., VAN HAREN G., MEIER M., GROBÉTY B., DAHMANN D. Airborne in-situ investigations of the Eyjafjallajökull volcanic ash plume on Iceland and over north-western Germany with light aircrafts and optical particle counters. Atmospheric Environment, 48, 9, 2012.

8. BARSOTTI S., ANDRONICO D., NERI A., DEL CARLO P., BAXTER P.J., ASPINALL W.P., HINCKS T. Quantitative assessment of volcanic ash hazards for health and infrastructure at Mt. Etna (Italy) by numerical simulation. Journal of Volcanology and Geothermal Research, 192, 85, 2010.

9. LÄHDE A., SÆUNN S., JOUTSENSAARI J., TAPPER U. In vitro evaluation of pulmonary deposition of airborne volcanic ash. Atmospheric Environment, 70, 18, 2013.

10. WULANINGSIH T., HUMAIDA H., HARIJOKO A., WATANABE K. Major Element and Rare Earth Elements Investigation of Merapi Volcano, Central Java, Indonesia. Procedia Earth and Planetary Science, 6, 202, 2013.

11. NAKAGAWA M., OHBA T. Minerals in Volcanic Ash 1: Primary Minerals and Volcanic Glass. Available online: https://pdfs.semanticscholar.org/ f7de/c7cda81d2fdcf36 e14b02416ae0a2dd427bd.pdf? $\mathrm{ga}=2.216120214 .1031767990 .1534072249-2102652230$. 1504770949 (accessed on 12 August 2018).

12. KUSMARTINI I., SYAHFITRI W.Y.N, KURNIAWATI S., LESTIANI D.D., SANTOSO M. Elemental characterization of Mt. Sinabung volcanic ash, Indonesia by Neutron Activation Analysis. Journal of Physics: Conference Series, 860, 2017.

13. CALABRESE S., ALESSANDRO W.D., BELLOMO S., BRUSCA L., MARTIN R.S., SAIANO F., PARELLO F. Characterization of the Etna volcanic emissions through an active biomonitoring technique (moss-bags): Part 1 Major and trace element composition. Chemosphere, 119, 1447, 2015.

14. LUMPP R., KLEIN M., BIEBER E., BUNZEL F., ECKERMANN U., FRELS C., GÜNTHER W., HAGEMANN C., KOCH C., OLSCHEWSKI A., TEMME C. Comparison of different digestion methods for elemental analysis of airborne dust and dust deposition [Vergleich verschiedener aufschlussverfahren zur elementbestimmung in schwebstaub und staubniederschlag]. GefahrstoffeReinhaltung Der Luft, 72, 64, 2012.

15. RUGGIERI F., FERNANDEZ-TURIEL J.L., SAAVEDRA J., GIMENO D., POLANCO E., AMIGO A., GALINDO G., CASELLI A., Contribution of volcanic ashes to the regional geochemical balance: The 2008 eruption of Chaitén volcano, Southern Chile. Science of The Total Environment, 425, 75, 2012.

16. CANION B., JACQUES C., LANDSBERGER S., TAFTAZANI A. Trace analysis of indonesian volcanic ash using thermal and epithermal neutron activation analysis. Nukleonika, 57, 585, 2012.

17. LIEKE K.I., KRISTENSEN T.B., KORSHOLM U.S., SØRENSEN J.H., K. KANDLER, WEINBRUCH S., CEBURNIS D., OVADNEVAITE J., DOWD C.D.O., 
BILDE M. Characterization of volcanic ash from the 2011 Grímsvötn eruption by means of single-particle analysis. Atmospheric Environment, 79, 411, 2013.

18. CRONIN S.J., STEWART C., ZERNACK A.V., BRENNA M., PROCTER J.N., PARDO N., CHRISTENSON B., WILSON T., STEWART R.B., IRWIN M. Volcanic ash leachate compositions and assessment of health and agricultural hazards from 2012 hydrothermal eruptions, Tongariro, New Zealand. Journal of Volcanology and Geothermal Research, 286, 233, 2014.
19. JANG B.K., FENG F.J., SUZUTA K., TANAKA H., MATSUSHITA Y., LEE K.S., KIM S., OH Y.S., KIM H.T. Corrosion behavior of volcanic ash on sintered mullite for environmental barrier coatings. Ceramics International, 43, 1880, 2017.

20. ILYINSKAYA E., TSANEV V.I., MARTIN R.S., OPPENHEIMER C., LE BLOND J. Near-source observations of aerosol size distributions in the eruptive plumes from Eyjafjallajökull volcano, March-April 2010. Atmospheric Environment, 45, 3210, 2011. 
